\title{
Pengaruh Model Brain Based Learning Ditinjau dari Kemampuan Berpikir Kritis Siswa
}

\author{
Ainun Fitriani ${ }^{1, *}$ \\ ${ }^{1}$ STKIP Taman Siswa Bima \\ ${ }^{1}$ ainunfitriani7@gmail.com \\ ${ }^{*}$ Coresponding Author
}

Artikel Info

Tanggal Publikasi

2019-06-30

Kata Kunci

Model Brain Based

Learning

Kemampuan

Berpikir Kritis Siswa

\section{Abstrak}

Penelitian ini bertujuan untuk mengetahui pengaruh model pembelajaran Brain Based Learning (BBL) terhadap kemampuan berpikir kritis siswa. Penelitian ini merupakan penelitian eksperimen semu (quasi eksperimen). Penelitian ini dilaksanakan di SMP Negeri 1 Kota Bima semester ganjil tahun pelajaran 2018/2019. Populasi penelitian adalah seluruh siswa kelas VIII dengan sampel penelitian siswa kelas VIII-1 dan VIII-2 yang masing-masing berjumlah 37 siswa. Pengumpulan data menggunakan tes serta instrumen pengumpulan data adalah tes kemampuan awal dan tes penguasaan materi operasi aljabar. Hasil penelitian menunjukkan bahwa terdapat pengaruh model Brain Based Learning (BBL) terhadap kemampuan berpikir kritis siswa.

\section{PENDAHULUAN}

Pendidikan menurut UU No 20 Tahun 2003 merupakan usaha sadar dan terencana untuk mewujudkan suasana belajar dan proses pembelajaran agar peserta didik secara aktif mengembangkan potensi dirinya yang diperlukan oleh dirinya, masyarakat, bangsa dan Negara. Faktanya, perwujudan suasana belajar ataupun proses pembelajaran seperti itu belum berjalan secara maksimal, karena subjek atau peserta didik untuk mewujudkan proses pembelajaran yang demikian belum optimal. Berarti dapat dikatakan bahwa kualitas mutu pendidikan di Indonesia masih rendah khususnya pada pembelajaran matematika.

Rendahnya mutu pendidikan matematika dapat dilihat dari kemampuan berpikir kritis siswa yang merupakan hal penting untuk ditingkatkan. Hal ini dapat dilihat dalam UU No 20 Tahun 2013 pada pasal 37 ayat 1 yang mengatakan bahwa kajian matematika antara lain berhitung, ilmu ukur, dan aljabar dimaksudkan untuk mengembangkan logika dan kemampuan berpikir peseta didik. Kemudian menurut (Ruggierro, 2012) kemampuan berpikir peserta didik terbagi menjadi 3 kategori yaitu reflektif, kreatif, dan kritis.

Pada kenyataannya kemampuan berpikir kritis siswa belum menunjukkan keberhasilan yang bagus. Hal ini ditunjukkan pada hasil penelitian yang dilakukan (Marin \& halpern, 2011) yang menjelaskan bahwa kemampuan berpikir kritis siswa yang terdaftar dalam program matematika tingkat bawah secara signifikan lebih rendah daripada tingkat atas. Jika kemampuan berpikir kritis siswa tingkat bawah memiliki standar yang cukup tinggi, maka ketika berada pada tingkat tinggi siswa akan memiliki kemampuan berpikir kritis yang lebih tinggi. Berarti dapat dikatakan bahwa kemampuan berpikir kritis siswa perlu ditingkatkan agar siswa siap menghadapi tantangan saat dihadapkan pada suatu masalah. 
Sesuai dengan Permendikbud No 54 Tahun 2013 tentang standar kompetensi lulusan pada kurikulum 2013, sasaran pembelajaran mencakup sikap, pengetahuan, dan keterampilan yang dielaborasi untuk setiap satuan pendidikan. Sasaran pembelajaran tersebut diupayakan dengan pembelajaran menggunakan pendcekatan saintifik. Pada dasarnya pembelajaran menggunakan pendekatan saintifik merupakan pembelajaran yang baik dan dapat memicu keaktifan siswa, dan lebih terstruktur dalam langkah-langkah pembelajarannya.

Proses pembelajaran yang belum berjalan secara maksimal juga dapat dipengaruhi oleh penggunaan model pembelajaran yang kurang efektif digunakan untuk meningkatkan kemampuan berpikir kritis siswa. Para guru biasanya menggunakan model konvensional untuk mengajar di kelas sedangkan model tersebut kurang mampu meningkatkan kemampuan berpikir kritis siswa dan siswa yang diajarkan dengan model pembelajaran konvensional lebih cepat bosan dan jenuh di dalam. Attard (2010) juga mengatakan bahwa pembelajaran konvensional cenderung menganggap siswa sebagai reseptor pasif informasi, tanpa pertimbangan untuk berpartisipasi aktif dalam proses pembelajaran. Oleh karena itu, diperlukan model pembelajaran yang efektif digunakan untuk meningkatkan kemampuan berpikir kritis siswa.

Model Brain Based Learning (BBL) dapat menjadi pilihan yang bagus untuk menangani masalah tantangan pembelajaran siswa. Karena unsur utama dalam model Brain Based Learning (BBL) adalah pembelajaran dengan masalah nyata yang dapat mengurangi kejenuhan siswa sehingga membuat siswa merasa bahwa pembelajaran matematika tidak selalu bersifat abstrak dan mampu diaplikasikan dalma kehidupan sehari-hari. Selain itu, model Brain Based Learning (BBL) juga memiliki unsur dimana siswa diberi kesempatan untuk melakukan refleksi, sehingga siswa mendapatkan waktu untuk meregangkan otot dan otak agar merasa nyaman dalam mengikuti pembelajaran.

Menurut (Jensen, 2011) Brain Based Learning (BBL) adalah pembelajaran yang dirancang sesuai dengan cara otak secara alamiah untuk belajar. (Sierck, 2012) juga berpendapat bahwa Brain Based Learning (BBL) didasarkan pada gagasan bahwa setiap bagian otak memiliki fungsi tertentu ketika berhubungan dengan pembelajaran. Sehingga tujuan dari penelitian ini adalah untuk mengetahui pengaruh model Brain Based Learning (BBL) ditinjau dari kemampuan berpikir kritis siswa.

\section{METODE PENELITIAN}

Jenis penelitian ini adalah eksperimen semu (quasi experiment). Penelitian ini menggunakan desain nonequivalent groups. Penelitian ini dilaksanakan di SMP Negeri 1 Kota Bima pada semester ganjil Tahun Pelajaran 2018/2019. Populasi dalam penelitian ini adalah seluruh siswa Kelas VIII SMP Negeri 1 Kota Bima dengan sampel penelitian siswa kelas VIII-1 dan VIII-2 yang masing-masing berjumlah 37 siswa.

Variabel dalam penelitian ini adalah variabel bebas yang merupakan model brain based learning dan variabel terikat yaitu kemampuan berpikir kritis siswa. Teknik pengumpulan data dalam penelitian ini melalui beberapa tahapan: menyusun instrumen penelitian berupa soal pretest dan posttest, Rencana Pelaksanaan Pembelajaran (RPP) model BBL dan Lembar Kerja Siswa (LKS) model BBL; memvalidasi isi instrumen dengan menggunakan validitas isi dan validitas konstruk yang berupa kisi-kisi soal pretest dan posttest, rubrik penskoran, dan angket; uji coba instrumen. 
Instrumen penelitian yang berupa tes kemampuan berpikir kritis siswa menggunakan soal bentuk uraianyang terdiri dari 4 (epat) aspek yaitu: kemampuan mengidentifikasi informasi; kemampuan menganalisis; kemampuan mengambil keputusan; kemampuan mengevaluasi.

Data yang dianalisis adalah data pretest dan posttest kemampuan berpikir siswa. Deskripsi data dilakukan melalui analisis deskriptif, data yang dideskripsikan merupakan data yang diperoleh dari pengukuran pada variabel terikat yaitu kemampuan berpikir kritis siswa. Data yang diperoleh dihitung nilai rata-ratanya kemudian dihitung standar deviasi, varians, skor maksimum dan minimum untuk data pretest dan psottest.

Data kemampuan berpikir kritis siswa yang dideskripsikan adalah nilai yang diperoleh siswa dari hasi tes dengan rentang nilai 1 sampai 10. Nilai tersebut akan akan dikelompokkan berdasarkan Kriteria ketuntasan Minimal (KKM). Model pembelajaran BBL dapat dikatakan terdapat pengaruh terhadap kemampuan berpikir kritis siswa jika nilai rata-rata siswa mencapai nilai KKM yang sudah ditetapkan yaitu 7,5.

\section{HASIL DAN PEMBAHASAN}

Adapun deskripsi data kemampuan berpikir kritis siswa sebelum dan sesudah diberi perlakuan model brain based learning ditunjukkan pada tabel berikut:

Tabel 1. Deskripsi Data Kemampuan Berpikir Kritis

\begin{tabular}{ccccc}
\hline \multirow{2}{*}{ Deskripsi } & \multicolumn{2}{c}{ VIII 1 } & \multicolumn{2}{c}{ VIII 2 } \\
\cline { 2 - 5 } & Pre test & Posttest & Pretest & Posttest \\
\hline Rata-rata & 5,27 & 9.36 & 4,5 & 6,5 \\
\hline Standar Deviasi & 1,21 & 0,56 & 1,53 & 0,66 \\
\hline Variansi & 1,79 & 0,31 & 2,32 & 0,54 \\
\hline Nilai Max Teoritik & 10 & 10 & 10 & 10 \\
\hline Nilai Min Teoritik & 0 & 0 & 0 & 0 \\
\hline Nilai Max Siswa & 5,2 & 9,49 & 4,5 & 6,5 \\
\hline Nilai Min Siswa & 2 & 7,9 & 1 & 5,75 \\
\hline
\end{tabular}

Berdasarkan tabel tersebut, dapat dijelaskan bahwa kemampuan berpikir kritis siswa kelas VIII1 untuk nilai rata-rata pretest dan posttest berturut-turut 5,27 dan 9,36 mengalami peningkatan sebesar 4,09. Sedangkan pada siswa kelas VII-2 nilai rata-rata pretest dan posttest berturut-turut 4,5 dan 6,5. Nilai standar deviasi pretest dan posttest untuk kelas VIII-1 berturut-turut 1,21 dan 0,56, sedangkan kelas VIII-2 beruturut-turut 1,53 dan 0,66. Untuk nilai variansi kelas VIII-1 pretest dan posttest adalah 1,79 dan 0,31 sedangkan kelas VIII-2 nilai variansinya adalah 2,32 dan 0,54. Nilai maksimum siswa kelas VIII-1 mengalami peningkatan sebesar 4,29 sedangkan kelas VIII-2 mengalami kenaikan sebesar 2. Untuk nilai minimum siswa kelas VIII-1 mendapat kenaikan sebesar 5,9 sedangkan kelas VIII-2 hanya 4,75.

Sebelum kedua kelas diberikan perlakuan, kondisi awal siswa memiliki kemampuan yang sama. Hal tersebut ditunjukkan oleh hasil uji homogenitas dan normalitas data kedua kelas menggunakan tes kemampuan awal. Hasil uji tersebut menunjukkan bahwa kedua kelas berdistribusi normal. Adapun langkah-langkah yang dilaksanakan dalam menerapkan model BBL adalah sebagai berikut: langkah pertama adalah mengamati dimana siswa diarahkan untuk mempelajari masalah yang 
ditemukan dan menyelesaikan masalah tersebut; langkah kedua adalah menanya dimana siswa diberikan sebuah masalah konkrit sehingga menimbulkan beberapa pertanyaan yang berkaitan dengan masalah tersebut.

Langkah selanjutnya dalah mengumpulkan informasi, siswa mencari informasi tambahan yang dibutuhkan untuk menyelesaikan masalah yang ditemui. Selanjutnya langkah mengasosiasi, dimana siswa menyelesaikan masalah dengan membentuk kelompok yang beranggotakan masing-masing 5-6 orang siswa. Langkah selanjutnya adalah mengkomunikasikan atau mengelaborasi, dimana siswa mempresentasikan hasil diskusi kelompok dan menunjuk salah satu dari anggota kelompok untuk menjadi juru bicara kelompok.

Berdasarkan langkah-langkah tersebut dapat dilihat bahwa model BBL dapat meningkatkan kemampuan berpikir kritis siswa terutama pada langkah mengasosiasikan.

\section{KESIMPULAN}

Berdasarkan hasil analisis dan pembahasan dapat disimpulkan bahwa terdapat pengaruh model Brain Based Learning (BBL) ditinjau dari kemampuan berpikir kritis siswa. Hal tersebut dapat dilihat dari nilai deskripsi data kemampuan berpikir kritis siswa kelas VIII-1 yang merupakan kelas eksperiman yang memiliki nilai lebih tinggi dibandingkan dengan kelas VIII-2 yang merupakan kelas kontrol.

\section{Daftar Pustaka}

Attard, A. (2010). Student Centered Learning: An insight theory and practice. Bucharest: Educational International.

Jensen, E (2011). Pembelajaran berbasis otak: paradigma pengajaran baru $(2 \wedge$ nded). (Penerjemah Drs. Benyamin Molan). Thousand Oaks, CA: Corwin Press. (Buku Asli diterbitkan tahn 2008).

Marin, L.M \& Halpern, D.F. (2011). Pedagogy for developing critical thinking in dolescents: explicit instruction produces greatest gain. Journal. Thinking Skill and Creativity 1-13.

Mendikbu. (2013). Peraturan Menteri Pendidikan dan Kebudayaan Nomor 54 tahun 2013, tentang Standar Kompetensi Lulusan.

Republik Indonesia. (2003). Undang-undang RI Nomor 20 Tahun 2003 tentang Sistem Pendidikan Nasional.

Ruggiero, V.R. (2012). Beyond feelings: a guide to critical thinking ( $\left.9^{\wedge}{ }^{\text {thed}}\right)$. New York: The McGraw-Hill Companies. Inc.

Siercks, A.M. (2012). Understanding and achieving brain based instruction in the elementary clasroom: a qualitative study of strategies used by teachers. Thesis master, tidak diterbitkan. University of Central Florida, Orlando, Florida, Amerika Serikat. 